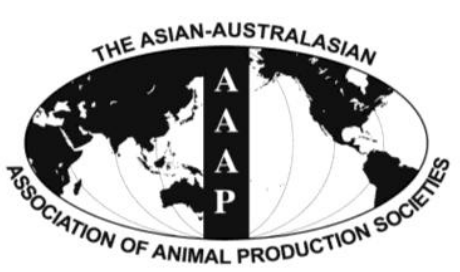

Open Access

Asian Australas. J. Anim. Sci.

Vol. 28, No. 4 : 544-550 April 2015

http://dx.doi.org/10.5713/ajas.14.0609

www.ajas.info

pISSN 1011-2367 elSSN 1976-5517

\title{
Effects of Heat-oxidized Soy Protein Isolate on Growth Performance and Digestive Function of Broiler Chickens at Early Age
}

\author{
X. Chen, Y. P. Chen, D. W. Wu, C. Wen, and Y. M. Zhou* \\ College of Animal Science and Technology, Nanjing Agricultural University, Nanjing 210095, China
}

\begin{abstract}
This study was conducted to investigate effects of heat-oxidized soy protein isolate (HSPI) on growth performance, serum biochemical indices, apparent nutrient digestibility and digestive function of broiler chickens. A total of 320 1-day-old Arbor Acres chicks were randomly divided into 4 groups with 8 replicates of 10 birds, receiving diets containing soy protein isolate (SPI, control group) or the same amount of SPI heated in an oven at $100^{\circ} \mathrm{C}$ for 1,4 , or $8 \mathrm{~h}$, for 21 days, respectively. The results indicated that compared with the control group, body weight gain and feed intake of birds fed diet containing SPI heated for $8 \mathrm{~h}$ were significantly lower $(\mathrm{p}<0.05)$. Serum urea nitrogen concentration was higher in the broilers fed diet containing SPI heated for 4 or $8 \mathrm{~h}$ at $\mathrm{d} 21$ ( $\mathrm{p}<0.05$ ). In contrast, serum glucose content was decreased by HSPI substitution at $d 21(p<0.05)$. The relative pancreas weight in HSPI groups was higher than that in the control group at $\mathrm{d} 21(\mathrm{p}<0.05)$. Meanwhile, the opposite effect was observed for relative weight of anterior intestine and ileum in broilers fed a diet containing SPI heated for $8 \mathrm{~h}(\mathrm{p}<0.05)$. Birds fed diets containing SPI heated for 4 or $8 \mathrm{~h}$ had a decreased lipase activity in anterior intestinal content at d 14 and $21(\mathrm{p}<0.05)$, respectively. In addition, the same effect was also noted in broilers given diets containing SPI heated for $1 \mathrm{~h}$ at d $21(\mathrm{p}<0.05)$. Similarly, amylase, protease and trypsin activity in anterior intestinal content were lower in broilers fed diets containing SPI heated for $8 \mathrm{~h}$ at d $21(\mathrm{p}<0.05)$. The apparent digestibility of dry matter $(\mathrm{DM})$ from d 8 to 10 and DM, crude protein (CP), and ether extract from d 15 to 17 were lower in broilers fed diets containing SPI heated for 8 $\mathrm{h}(\mathrm{p}<0.05)$. Besides, birds given diets containing SPI heated for $4 \mathrm{~h}$ also exhibited lower CP apparent digestibility from $\mathrm{d} 15$ to 17 $(p<0.05)$. It was concluded that HSPI inclusion can exert a negative influence on the growth performance of broilers, which was likely to result from the simultaneously compromised digestive function. (Key Words: Broilers, Digestion, Growth Performance, Heat-oxidized Soy Protein Isolate)
\end{abstract}

\section{INTRODUCTION}

Protein has been known to be the most important nutrient in animal feed, providing not only amino acids for body protein synthesis, but also energy for growth (Korhonen et al., 1998). Protein quality plays vital role in protein digestibility and utilization. Protein oxidation is the structural modification induced directly by reactive oxygen species or indirectly by reaction with the by-products of lipid peroxidation (Shacter, 2000). During processing and storage, food protein can be easily affected by various factors, such as heat, comminuting and grinding, which introduce molecular oxygen and mix oxidants with

* Corresponding Author: Y. M. Zhou. Tel: +86-025-84396067, Fax: +86-025-84395314, E-mail: zhouym6308@163.com

Submitted Aug. 11, 2014; Revised Sept. 20, 2014; Accepted Oct. 14, 2014 susceptible food components (Korhonen et al., 1998). Oxidative modification of proteins has been shown to induce a number of multiple structural changes such as oxidation of side chains of special amino acid residues and peptide chains in protein, fragmentation, aggregation, and changes in hydrophobicity as well as conformation (Headlam and Davies, 2004). Ultimately, these alterations often result in changes in functional properties and bioavailability of protein (Witko-Sarsat et al., 2003; Smet et al., 2008; Zhang et al., 2011). Studies have claimed that oxidative modification of protein can lead to altered digestibility of proteins in vitro and susceptibility of protein to protein-degrading enzymes. Zamora and Hidalgo (2001) reported that proteolytic susceptibility of proteins to chymotrypsin, pancreatin, pronase and trypsin was decreased by oxidative modification induced by lipid 
peroxidation. Similarly, Sante-Lhoutellier et al. (2007) found a direct and quantitative relationship between oxidized myofibrillar proteins caused by hydroxyl radical and decreased proteolytic susceptibility to proteases of the digestive tract. Moreover, it was reported that heat oxidation led the soy protein to generate reactive oxygen species, decrease the antioxidant status and induce redox imbalance in digestive organs of mice fed heat-oxidized soybean protein (Tang et al., 2012a). Besides, heat-oxidized soy protein isolate (HSPI) also caused compromised growth performance and inferior immune function of broilers (Wu et al., 2014). These studies provide evidences that oxidative modification may adversely affect protein digestibility and digestive function of animals. Nevertheless, few studies have been carried out concerning the effects of dietary oxidized protein on growth performance and digestive function of broilers.

Heating is one of the most common and widely used methods in many different food products to modify proteins (Tang et al., 2012b; Wu et al., 2014). Soy protein isolate (SPI) is used as a functional ingredient in many different food products and it has been reported that SPI is usually subjected to heating during processing (Renkema et al., 2002; Tang et al., 2009; Wu et al., 2014). Therefore, SPI heated in an oven at $100^{\circ} \mathrm{C}$ for 1,4 , and $8 \mathrm{~h}$, respectively, were used in this study and the aim was to determine whether dietary oxidized protein would have any negative effects on the growth performance and digestive function of broilers at early age.

\section{MATERIAL AND METHODS}

\section{Materials}

SPI was purchased from Sun-Green Biotech Co., Ltd. (Nantong, China). Analyzed moisture, crude protein (CP), ether extract (EE) and ash contents in the SPI were 5.6\%, $86.2 \%, 0.4 \%$ and $4.9 \%$, respectively. The HSPI was prepared according to the method as described by Tang et al. (2012a, b) and $\mathrm{Wu}$ et al. (2014). $1.0 \mathrm{~kg}$ native SPI was evenly placed on clean and dry stainless steel tray (Length $\times$ Width $\times$ Height: $14 \mathrm{~cm} \times 8 \mathrm{~cm} \times 2 \mathrm{~cm}$ ) and was dry heated at $100^{\circ} \mathrm{C}(1,4,8 \mathrm{~h})$, then air-dried under normal condition (around $25^{\circ} \mathrm{C}$ ) and stored at $4^{\circ} \mathrm{C}$. Protein carbonyl content in SPI heated for $4 \mathrm{~h}(17.80 \mathrm{nmol} / \mathrm{mg}$ prot $)$, and $8 \mathrm{~h}$ ( $22.35 \mathrm{nmol} / \mathrm{mg}$ prot) were significantly higher than normal SPI (15.13 nmol/mgp rot) and SPI heated for $1 \mathrm{~h}$ (15.79 $\mathrm{nmol} / \mathrm{mg}$ prot).

\section{Experimental design, diets and management}

All experimental conditions and animal procedures were approved by Nanjing Agricultural University Institutional Animal Care and Use Committee. A total of 3201 day-old Arbor Acres broiler chicks $(45.01 \pm 0.07 \mathrm{~g})$ from a commercial hatchery (Hewei Co., Ltd, Anhui, China) were used in this study. The birds were randomly divided into 4 groups with 8 replicates of 10 birds and were fed a diet containing normal SPI (Control) or diets containing the same amount of SPI heated in an oven at $100^{\circ} \mathrm{C}$ for 1,4 , and $8 \mathrm{~h}$, respectively. The experiment lasted for $21 \mathrm{~d}$. The basal diet was formulated based on the NRC (1994) to meet the nutrient requirements of the broiler. The formulation and nutrient level of basal diet were shown in Table 1.

Birds were housed in an environmentally controlled room. Temperature was maintained at $32^{\circ} \mathrm{C}$ for the first week and then gradually reduced, according to normal management practices, until a temperature of $26^{\circ} \mathrm{C}$ was achieved. Continuous light was provided throughout the entire experiment. Mash feed and fresh water were available ad libitum at all growth phase. Body weight and feed intake during the 21-d experiment (measured at 1 and $21 \mathrm{~d}$ after deprivation of feed for $12 \mathrm{~h}$, with water being provided ad libitum) were recorded to calculate body weight gain, feed intake and feed conversion rate.

\section{Sample collection}

On d 14 and 21, 8 birds from each treatment (one bird per cage) were randomly selected and weighed after feed deprivation for $12 \mathrm{~h}$. Blood samples were collected from the wing vein. Serum samples were then taken by centrifugation at $3,000 \times \mathrm{g}$ for $15 \mathrm{~min}$ at $4{ }^{\circ} \mathrm{C}$ and stored at

Table 1. The formulation and calculated nutrient levels of basal diet (\%, as-fed basis unless otherwise stated)

\begin{tabular}{|c|c|}
\hline Ingredients & Content \\
\hline Corn & 78.47 \\
\hline Soy protein isolate & 16.50 \\
\hline Limestone & 1.40 \\
\hline Dicalcium phosphate & 1.95 \\
\hline Sodium chloride & 0.30 \\
\hline L-lysine & 0.20 \\
\hline DL-methionine & 0.18 \\
\hline Premix $^{a}$ & 1.0 \\
\hline Apparent metabolizable energy $(\mathrm{MJ} / \mathrm{kg})$ & 13.0 \\
\hline Crude protein & 21.0 \\
\hline Calcium & 0.98 \\
\hline Available phosphorus & 0.46 \\
\hline Lysine & 1.21 \\
\hline Methionine & 0.53 \\
\hline Methionine+cysteine & 0.83 \\
\hline \multicolumn{2}{|c|}{$\begin{array}{l}\text { a Premix provided per kilogram of diet: transretinyl acetate, } 24 \mathrm{mg} \text {; } \\
\text { cholecalciferol, } 6 \mathrm{mg} \text {; all-rac- } \alpha \text {-tocopherol acetate, } 20 \mathrm{mg} \text {; menadione, } \\
1.3 \mathrm{mg} \text {; thiamin, } 2.2 \mathrm{mg} \text {; riboflavin, } 8 \mathrm{mg} \text {; nicotinamide, } 40 \mathrm{mg} \text {; choline } \\
\text { chloride, } 400 \mathrm{mg} \text {; calcium pantothenate, } 10 \mathrm{mg} \text {; pyridoxine. } \mathrm{HCl}, 4 \mathrm{mg} \text {; } \\
\text { biotin, } 0.04 \mathrm{mg} \text {; folic acid, } 1 \mathrm{mg} \text {; vitamin } \mathrm{B}_{12} \text { (cobalamin), } 0.013 \mathrm{mg} \text {; Fe } \\
\text { (from ferrous sulfate), } 80 \mathrm{mg} \text {; Cu (from copper sulfate), } 7.5 \mathrm{mg} \text {; Mn } \\
\text { (from manganese sulfate), } 110 \mathrm{mg} \text {; Zn (from zinc oxide), } 65 \mathrm{mg} \text {; (from } \\
\text { calcium iodate), } 1.1 \mathrm{mg} \text {; Se (from sodium selenite), } 0.3 \mathrm{mg} \text {; bacitracin } \\
\text { zinc, } 30 \mathrm{mg} \text {. }\end{array}$} \\
\hline
\end{tabular}


$-20^{\circ} \mathrm{C}$ until analysis (Chen et al., 2013). After blood sampling, birds were killed by cervical dislocation immediately. The proventriculus, gizzard, pancreas, duodenum (from ventriculus to pancreo-biliary ducts), jejunum (from pancreo-biliary ducts to yolk stalk) and ileum (from yolk stalk to ileocecal junction) were removed and weighed (without content and gall bladder). Relative organ weight was calculated according to following formula (Wu et al., 2014): relative weight of digestive organs (g per $100 \mathrm{~g}$ body weight $)=$ organ weight $(\mathrm{g}) /$ body weight $(100 \mathrm{~g})$. After that, contents within anterior intestine (duodenum and jejunum) were collected by massaging the tract from both ends into plastic containers and stored at $-20^{\circ} \mathrm{C}$ until analysis.

\section{Serum biochemistry}

Serum urea nitrogen (UN, berthelot color reaction method), total protein (TP, biuret method), albumin (ALB, bromocresol green method), triglyceride (TG, glycerol kinase method), total cholesterol (TC, cholesterol esterase/peroxidase method) and glucose (GLU, glucose oxidase method) were determined on a biochemical autoanalyzer (Beckman Instruments, Inc. Scientific Instruments Division, Fullerton, CA, USA) according to the manufacturer's recommended procedure (Fossati and Prencipe, 1982; Thomas et al., 1982; Deeg and Ziegenhorn, 1983; Denli et al., 2009).

\section{Digestive enzyme assay}

Anterior intestinal content samples were homogenized (1:9, wt/vol) with ice-cold $154 \mathrm{mmol} / \mathrm{L}$ sodium chloride solution, and then centrifuged at $4,550 \times g$ for $15 \mathrm{~min}$ at $4^{\circ} \mathrm{C}$. The supernatants were divided into small portions and stored for enzyme activity assay. Enzymes activities were determined according to method used in our lab as described by Wen et al. (2012). In detail, enterokinase was added to homogenate to activate pancreatic zymogens before determination of pancreatic trypsin and protease. Amylase activity was determined using the iodometric method and one amylase unit was defined as the amount of enzyme that hydrolyzed $10 \mathrm{mg}$ of starch in $30 \mathrm{~min}$. Protease activity was assayed using casein as substrate and reacting it with Folin reagent. One protease unit was defined as the amount of enzyme that hydrolyzed casein to form $1 \mu \mathrm{mol}$ product per min. Trypsin activity was assessed using $\mathrm{N}$ benzoyl-1-arginine ethyl ester as substrate. One unit of trypsin was defined as the amount of enzyme that increased 0.003 of absorbance of product per minute. Lipase activity was determined using a turbidimetric method and one lipase unit was defined as the amount of enzyme that hydrolyzed 1 $\mu \mathrm{mol}$ of olive oil per min. Protein concentration was determined using bovine ALB as a standard. Amylase and protease activities were expressed as units per milligram of protein, trypsin activity was expressed as units per microgram of protein, and lipase activity was expressed as units per gram of protein.

\section{Digestibility determination}

During days 8 to 10 and 15 to 17 , uncontaminated excreta (free from feathers and feed) were collected twice per day $(0800$ and $1600 \mathrm{~h})$ from each cage. The excreta samples from the three collections from each cage were pooled and then dried for $48 \mathrm{~h}$ in an oven at $65^{\circ} \mathrm{C}$. The dried excreta were allowed to equilibrate to atmospheric conditions for $24 \mathrm{~h}$ before being weighed. Feed and excreta samples were then ground through a $0.45-\mathrm{mm}$ screen and subsequently analyzed (AOAC, 1990) for dry matter (DM, 934.01), EE (920.39) and CP (954.01). Apparent digestibility was determined using acid-insoluble ash (Acidinsoluble, 920.72) as the indicator and was expressed as \%.

\section{Statistical analysis}

All data were analyzed as a completely randomized design using one-way analysis of variance with Duncan multiple comparison test (SPSS, 2008). The differences were considered to be significant at $\mathrm{p}<0.05$. The $\mathrm{p}$ values between 0.05 and 0.10 were considered as a trend.

\section{RESULTS}

\section{Growth performance}

As expected (Table 2), the body weight and feed intake were lower in HSPI groups especially the SPI heated for $8 \mathrm{~h}$ group $(\mathrm{p}<0.05)$ when compared with the control. However, feed conversion ratio was not affected by HSPI ( $p>0.05)$.

\section{Serum biochemical indices}

Dietary HSPI can cause an increase in serum UN

Table 2. Effects of heat-oxidized soy protein isolate on growth performance of broilers

\begin{tabular}{|c|c|c|c|c|c|c|}
\hline \multirow{2}{*}{ Item } & \multirow{2}{*}{ Control } & \multicolumn{3}{|c|}{ Heat treatment group $^{1}$} & \multirow{2}{*}{ SEM } & \multirow{2}{*}{$\mathrm{p}$ value } \\
\hline & & $1 \mathrm{~h}$ & $4 \mathrm{~h}$ & $8 \mathrm{~h}$ & & \\
\hline Body weight gain (g/bird) & $524^{x}$ & $496^{x y}$ & $493^{x y}$ & $481^{y}$ & 6 & 0.043 \\
\hline Feed intake (g/bird) & $814^{\mathrm{x}}$ & $797^{x y}$ & $787^{\mathrm{xy}}$ & $756^{y}$ & 9 & 0.038 \\
\hline Feed/gain ratio & 1.55 & 1.61 & 1.60 & 1.57 & 0.01 & 0.887 \\
\hline
\end{tabular}

SEM, standard error of means $(n=8)$.

${ }^{1}$ Soy protein isolate heated at $100^{\circ} \mathrm{C}$ for 1,4 , and $8 \mathrm{~h}$, respectively.

${ }^{\mathrm{x}, \mathrm{y}}$ Means within a row without a common superscripts differ significantly $(\mathrm{p}<0.05)$. 
Table 3. Effects of heat-oxidized soy protein isolate on serum biochemical indices of broilers

\begin{tabular}{|c|c|c|c|c|c|c|}
\hline \multirow{2}{*}{ Item } & \multirow{2}{*}{ Control } & \multicolumn{3}{|c|}{ Heat treatment group } & \multirow{2}{*}{ SEM } & \multirow{2}{*}{$\mathrm{p}$ value } \\
\hline & & $1 \mathrm{~h}$ & $4 \mathrm{~h}$ & $8 \mathrm{~h}$ & & \\
\hline \multicolumn{7}{|l|}{$14 \mathrm{~d}$} \\
\hline $\mathrm{UN}(\mathrm{mmol} / \mathrm{L})$ & 0.30 & 0.33 & 0.33 & 0.35 & 0.01 & 0.456 \\
\hline GLU (mmol/L) & 11.61 & 10.74 & 10.70 & 10.96 & 0.16 & 0.173 \\
\hline $\mathrm{TC}(\mathrm{mmol} / \mathrm{L})$ & 2.91 & 2.81 & 2.75 & 2.70 & 0.05 & 0.568 \\
\hline TG (mmol/L) & 0.37 & 0.36 & 0.37 & 0.34 & 0.02 & 0.968 \\
\hline $\mathrm{TP}(\mathrm{g} / \mathrm{L})$ & 24.15 & 24.80 & 24.22 & 23.37 & 0.57 & 0.873 \\
\hline $\operatorname{ALB}(\mathrm{g} / \mathrm{L})$ & 12.15 & 12.02 & 12.53 & 12.32 & 0.32 & 0.951 \\
\hline \multicolumn{7}{|l|}{$21 \mathrm{~d}$} \\
\hline $\mathrm{UN}(\mathrm{mmol} / \mathrm{L})$ & $0.30^{\mathrm{y}}$ & $0.34^{x y}$ & $0.36^{\mathrm{x}}$ & $0.40^{\mathrm{x}}$ & 0.01 & 0.016 \\
\hline GLU (mmol/L) & $13.23^{\mathrm{x}}$ & $11.72^{\mathrm{y}}$ & $11.54^{\mathrm{y}}$ & $11.59^{\mathrm{y}}$ & 0.27 & 0.035 \\
\hline $\mathrm{TC}(\mathrm{mmol} / \mathrm{L})$ & 2.71 & 2.68 & 2.32 & 2.24 & 0.08 & 0.108 \\
\hline TG (mmol/L) & 0.45 & 0.45 & 0.44 & 0.43 & 0.02 & 0.971 \\
\hline $\mathrm{TP}(\mathrm{g} / \mathrm{L})$ & 27.88 & 27.58 & 27.98 & 27.42 & 0.57 & 0.980 \\
\hline $\operatorname{ALB}(\mathrm{g} / \mathrm{L})$ & 13.45 & 13.43 & 13.55 & 12.35 & 0.38 & 0.669 \\
\hline
\end{tabular}

SEM, standard error of means $(n=8)$; UN, serum urea nitrogen; GLU, glucose; TC, total cholesterol; TG, triglyceride; TP, total protein; ALB, albumin

${ }^{\mathrm{x}, \mathrm{y}}$ Means within a row without a common superscripts differ significantly $(\mathrm{p}<0.05)$

content and this negative effect was more pronounced in long-term heat-oxidized SPI groups as demonstrated by significantly increased UN content in broilers fed diets containing SPI heated for $4 \mathrm{~h}(0.30 \mathrm{vs} 0.36 \mathrm{mmol} / \mathrm{L})$ or $8 \mathrm{~h}$ $(0.30$ vs $0.40 \mathrm{mmol} / \mathrm{L})$ at $\mathrm{d} 21(\mathrm{p}<0.05)$ when compared with the control (Table 3). In contrast, dietary HSPI inclusion significantly decreased serum GLU content at $d$ $21(\mathrm{p}<0.05)$. Other serum biochemical indices (TC, TG, TP, and ALB) were unaffected by HSPI substitution ( $p>0.05$ ).

\section{Organs weights}

As summarized in Table 4, no significant differences were noticed for the relative proventriculus or gizzard weight among groups at both d 14 and 21 ( $>>0.05$ ). Compared with the control group, dietary HSPI resulted in a significant increase in the relative pancreas weight at $\mathrm{d} 21$ $(\mathrm{p}<0.05)$. In contrast, relative anterior intestine and ileum weight were significantly decreased by SPI heated for $8 \mathrm{~h}$ at d $21(p<0.05)$, but this effect was not observed in the other HSPI groups $(p>0.05)$.

\section{Digestive enzyme activity}

There were no significant (Table 5) differences in amylase, protease, and trypsin activity among groups at $\mathrm{d}$ 14 (p>0.05), however, the activities of those enzymes were significantly decreased by SPI heated for $8 \mathrm{~h}$ as compared with control group at $\mathrm{d} 21(\mathrm{p}<0.05)$. As for the lipase, broilers fed diets containing SPI heated for $4 \mathrm{~h}$ or $8 \mathrm{~h}$ exhibited a significantly lower activity than those in control group at either $\mathrm{d} 14$ or $21(\mathrm{p}<0.05)$, and the same effect was

Table 4. Effects of heat-oxidized soy protein isolate on relative weight of digestive organs $(\mathrm{g} / 100 \mathrm{~g}$ body weight) of broilers

\begin{tabular}{|c|c|c|c|c|c|c|}
\hline \multirow{2}{*}{ Item } & \multirow{2}{*}{ Control } & \multicolumn{3}{|c|}{ Heat treatment group } & \multirow{2}{*}{ SEM } & \multirow{2}{*}{$\mathrm{p}$ value } \\
\hline & & $1 \mathrm{~h}$ & $4 \mathrm{~h}$ & $8 \mathrm{~h}$ & & \\
\hline \multicolumn{7}{|l|}{$14 \mathrm{~d}$} \\
\hline Gizzard & 3.39 & 3.23 & 3.25 & 3.17 & 0.07 & 0.722 \\
\hline Proventriculus & 0.70 & 0.68 & 0.70 & 0.67 & 0.01 & 0.709 \\
\hline Pancreas & 0.47 & 0.49 & 0.50 & 0.50 & 0.01 & 0.771 \\
\hline Anterior intestine & 4.22 & 4.26 & 4.23 & 4.16 & 0.08 & 0.427 \\
\hline Ileum & 1.10 & 1.10 & 1.09 & 1.03 & 0.03 & 0.758 \\
\hline \multicolumn{7}{|l|}{$21 \mathrm{~d}$} \\
\hline Gizzard & 2.66 & 2.63 & 2.69 & 2.59 & 0.05 & 0.928 \\
\hline Proventriculus & 0.58 & 0.56 & 0.58 & 0.56 & 0.01 & 0.914 \\
\hline Pancreas & $0.35^{\mathrm{y}}$ & $0.40^{\mathrm{x}}$ & $0.41^{\mathrm{x}}$ & $0.42^{\mathrm{x}}$ & 0.01 & 0.014 \\
\hline Anterior intestine & $2.67^{x}$ & $2.56^{\mathrm{xy}}$ & $2.60^{x y}$ & $2.33^{\mathrm{y}}$ & 0.05 & 0.047 \\
\hline Ileum & $0.97^{\mathrm{x}}$ & $0.97^{\mathrm{x}}$ & $0.96^{\mathrm{x}}$ & $0.83^{\mathrm{y}}$ & 0.02 & 0.039 \\
\hline
\end{tabular}

SEM, standard error of means $(n=8)$.

${ }^{\mathrm{x}, \mathrm{y}}$ Means within a row without a common superscripts differ significantly $(\mathrm{p}<0.05)$. 
Table 5. Effects of heat-oxidized soy protein isolate on digestive enzyme activities within anterior intestinal contents of broilers

\begin{tabular}{|c|c|c|c|c|c|c|}
\hline \multirow{2}{*}{ Item } & \multirow{2}{*}{ Control } & \multicolumn{3}{|c|}{ Heat treatment group } & \multirow{2}{*}{ SEM } & \multirow{2}{*}{$\mathrm{p}$ value } \\
\hline & & $1 \mathrm{~h}$ & $4 \mathrm{~h}$ & $8 \mathrm{~h}$ & & \\
\hline \multicolumn{7}{|l|}{$14 \mathrm{~d}$} \\
\hline Amylase(U/mg prot) & 89.91 & 78.10 & 76.03 & 70.46 & 7.62 & 0.837 \\
\hline Protease (U/mg prot) & 225.95 & 214.44 & 203.72 & 190.98 & 11.04 & 0.732 \\
\hline Lipase (U/g prot) & $256.56^{\mathrm{x}}$ & $197.91^{x y}$ & $177.94^{\mathrm{y}}$ & $170.96^{\mathrm{y}}$ & 11.71 & 0.026 \\
\hline 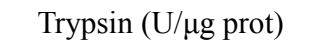 & 30.46 & 27.12 & 26.64 & 26.34 & 0.91 & 0.312 \\
\hline \multicolumn{7}{|l|}{$21 \mathrm{~d}$} \\
\hline Amylase(U/mg prot) & $82.51^{\mathrm{x}}$ & $72.12^{\mathrm{xy}}$ & $62.49^{x y}$ & $56.69^{y}$ & 4.19 & 0.048 \\
\hline Protease (U/mg prot) & $216.48^{x}$ & $196.55^{\mathrm{xy}}$ & $168.25^{x y}$ & $157.01^{y}$ & 9.42 & 0.037 \\
\hline Lipase (U/g prot) & $189.89^{x}$ & $130.46^{\mathrm{y}}$ & $124.06^{\mathrm{y}}$ & $104.04^{y}$ & 11.16 & 0.032 \\
\hline 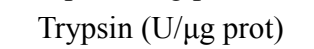 & $33.92^{\mathrm{x}}$ & $31.17^{\mathrm{xy}}$ & $28.92^{x y}$ & $27.63^{y}$ & 0.89 & 0.038 \\
\hline
\end{tabular}

SEM, sandard error of means $(n=8)$.

${ }^{\mathrm{x}, \mathrm{y}}$ Means within a row without a common superscripts differ significantly $(\mathrm{p}<0.05)$

also observed in broilers given SPI heated for $1 \mathrm{~h}$ at $\mathrm{d} 21$ $(\mathrm{p}<0.05)$.

\section{Apparent digestibility of nutrients}

HSPI substitution (Table 6) did not affect the apparent digestibility of $\mathrm{CP}$ and EE from d 8 to 10 ( $\mathrm{p}>0.05)$. As expected, compared with control, the apparent digestibility of DM of birds from d 8 to 10 and DM, CP and EE from d 15 to 17 were significantly decreased by SPI heated for $8 \mathrm{~h}$ $(\mathrm{p}<0.05)$. Besides, birds given diet containing SPI heated for $4 \mathrm{~h}$ also exhibited lower CP apparent digestibility from d 15 to $17(\mathrm{p}<0.05)$.

\section{DISCUSSION}

Our study has shown that HSPI inclusion significantly decreased body weight gain of broilers, which was likely the result from simultaneously compromised feed intake rather than similar feed conversion ratio. Similar result was also observed by Tang et al. (2012a) in mice and in broilers by $\mathrm{Wu}$ et al. (2014). The inferior growth performance was due to inferior digestive function discussed in the following.

Serum biochemistry is a labile biochemical system which can reflect the condition of the organism and the changes happening to it under influence of internal and external factors. In the current study, broilers fed diets containing HSPI exhibited lower serum GLU level. The decrease in the serum GLU level was quite interesting because birds generally maintain a high and relatively constant serum GLU level even in low feed intake (Liukkonen-Anttila, 2001). We would likely to attribute the lower GLU content to the inferior nutrient digestion capacity of birds fed HSPI diets. Changes in serum UN concentration can reflect the whole body status of amino acid metabolism and utilization in animals. Increased accretion of serum UN concentration would suggest a potential attenuation of synthesis of protein in animals. Previous studies have indicated that oxidative modification adversely affects numerous amino acids in protein or peptides (Stadtman, 1990; Wu et al., 2014). Therefore, changes of amino acid composition in HSPI may be responsible for the deterioration of synthesis of protein in broilers. In the present study, serum UN of broilers was significantly higher in broilers fed diets containing SPI heated for 4 and $8 \mathrm{~h}$, suggesting that oxidative modification may decline the protein quality and utilization of the diet.

The relative weight is one of the primary biological characteristics of digestive organs and the metabolic

Table 6. Effects of heat-oxidized soy protein isolate on apparent nutrient digestibility of broilers (\%)

\begin{tabular}{|c|c|c|c|c|c|c|}
\hline \multirow{2}{*}{ Item } & \multirow{2}{*}{ Control } & \multicolumn{3}{|c|}{ Heat treatment group } & \multirow{2}{*}{ SEM } & \multirow{2}{*}{$\mathrm{p}$ value } \\
\hline & & $1 \mathrm{~h}$ & $4 \mathrm{~h}$ & $8 \mathrm{~h}$ & & \\
\hline \multicolumn{7}{|l|}{8 to $10 \mathrm{~d}$} \\
\hline Dry matter & $80.22^{\mathrm{x}}$ & $79.21^{\mathrm{xy}}$ & $79.22^{x y}$ & $78.11^{\mathrm{y}}$ & 0.35 & 0.049 \\
\hline Crude protein & 71.63 & 69.77 & 69.76 & 69.01 & 0.55 & 0.370 \\
\hline Ether extract & 77.36 & 73.10 & 74.93 & 72.60 & 0.85 & 0.181 \\
\hline \multicolumn{7}{|l|}{15 to $17 \mathrm{~d}$} \\
\hline Dry matter & $80.60^{x}$ & $79.25^{x y}$ & $78.97^{x y}$ & $77.53^{y}$ & 0.36 & 0.029 \\
\hline Crude protein & $68.55^{\mathrm{x}}$ & $65.63^{x y}$ & $64.27^{\mathrm{y}}$ & $64.15^{\mathrm{y}}$ & 0.66 & 0.030 \\
\hline Ether extract & $74.76^{\mathrm{x}}$ & $64.23^{x y}$ & $65.80^{x y}$ & $62.61^{\mathrm{y}}$ & 1.91 & 0.038 \\
\hline
\end{tabular}

SEM, standard error of means $(n=8)$.

${ }^{\mathrm{x}, \mathrm{y}}$ Means within a row without a common superscripts differ significantly $(\mathrm{p}<0.05)$. 
activity of digestive organs is a function of the metabolic activity and size of the organs. In the current study, the relative pancreas weight of broilers fed HSPI was significantly heavier than that of the control group at $\mathrm{d} 21$, indicating that oxidized protein can probably cause compensatory hypertrophy of pancreas, which may be due to changes in pancreatic cellular hypertrophy and cell number induced by HSPI inclusion ( $\mathrm{Gu}$ and $\mathrm{Hu}, 2010$ ). In addition, Mahmood et al. (1997) reported that lower feed intake itself could induce an increase in the relative weight of the pancreas. Therefore, the pancreatic hypertrophy may also result from the lower feed intake in broilers fed diets containing HSPI. Effects of HSPI inclusion on relative weight of other digestive organs were quite different from pancreas. In the current study, relative anterior intestine and ileum weight showed a significantly decrease in broilers fed a diet containing SPI heated for $8 \mathrm{~h}$ at $\mathrm{d} 21$. These combined changes indicate that oxidized protein may have a negative impact on the development digestive tracts and organs, and the impairment may be due to growth depression observed in broilers fed HSPI.

Digestive enzymes in the intestine of poultry are mainly synthesized by and secreted from the pancreas. However, they can only be activated in the gut and then play their expected roles. Therefore, changes of intestinal enzymes will illustrate the development of the digestive process. Rideau et al. (1983) observed that intestinal enzymes were located mainly in the duodenum or jejunum in the chicken. In the current study, we therefore selected digestive enzymes present in the anterior intestine (duodenum and jejunum) as an indicator of intestinal digestive enzymes activities. Our data showed that HSPI inclusion decreased the amylase, protease, lipase and trypsin activities. The lower small intestinal enzyme activities observed in birds fed HSPI may be responsible for the impairment of growth performance because it is well known that digestive enzymes play a rate-determining role in providing the substrates for growth. Recently, it has been demonstrated in many studies that oxidative modification is responsible for the protein aggregation and the consequent decrease of digestibility (Gatellier et al., 2009; Promeyrat et al., 2010). In the current study, the decrease in the apparent digestibility of DM, CP, and EE of broilers fed diets containing HSPI was consistent with the study of Tang et al. (2012a), who reported that ingestion of a HSPI diet resulted in a significant decrease in apparent digestibility of the DM and $\mathrm{CP}$ in mice. It may then be inferred that ingesting diets containing oxidized protein can cause a negative effect on nutrient digestibility of broilers.

In conclusion, our study indicated that ingesting diets containing HSPI exerted a negative influence on growth performance and digestive function of broiler chickens as indicated by various measured parameters. More studies are needed to explain the precise mechanism involved in the modification of feed protein, and the potential health risk in animals induced by oxidized protein inclusion.

\section{ACKNOWLEDGMENTS}

We gratefully thank our labmates in the College of Animal Science and Technology of Nanjing Agricultural University for their assistant in this study. This work was supported by the Postgraduate Education Innovation Project of Jiangsu province in China (CXLX13-289).

\section{REFERENCES}

AOAC. 1990. Official Methods of Analysis, 15th edn. Association of Official Analytical Chemists, Arlington, VA, USA.

Chen, Y. P., X. Chen, H. Zhang, and Y. M. Zhou. 2013. Effects of dietary concentrations of methionine on growth performance and oxidative status of broiler chickens with different hatching weight. Br. Poult. Sci. 54:531-537.

Deeg, R. and J. Ziegenhorn. 1983. Kinetic enzymatic method for automated determination of total cholesterol in serum. Clin. Chem. 29:1798-1802.

Denli, M., J. C. Blandon, M. E. Guynot, S. Salado, and J. F. Perez. 2009. Effects of dietary AflaDetox on performance, serum biochemistry, histopathological changes, and aflatoxin residues in broilers exposed to aflatoxin $\mathrm{B}_{1}$. Poult. Sci. 88:1444-1451.

Fossati, P. and L. Prencipe. 1982. Serum triglycerides determined colorimetrically with an enzyme that produces hydrogen peroxide. Clin. Chem. 28:2077-2080.

Gatellier, P., V. Santé-Lhoutellier, S. Portanguen, and A. Kondjoyan. 2009. Use of meat fluorescence emission as a marker of oxidation promoted by cooking. Meat Sci. 83:651656.

Gu, C. and H. Xu. 2010. Effect of oxidative damage due to excessive protein ingestion on pancreas function in mice. Int. J. Mol. Sci. 11:4591-4600.

Headlam, H. A. and M. J. Davies. 2004. Markers of protein oxidation: Different oxidants give rise to variable yields of bound and released carbonyl products. Free Radic. Biol. Med. 36:1175-1184.

Korhonen, H., A. Pihlanto-Leppäla, P. Rantamäki, and T. Tupasela. 1998. Impact of processing on bioactive proteins and peptides. Trends Food Sci. Technol. 9:307-319.

Liukkonen-Anttila, T. 2001. Nutritional and Genetic Adaptation of Galliform Birds: Implications for Hand-rearing and Restocking. PhD Thesis, University of Oulu, Oulu, Finland. 73.

Mahmood, S., R. Smithard, and M. Sarwar. 1997. Effects of salseed (Shorea robusta) tannins, restricted feed intake and age on relative pancreas weight and activity of digestive enzymes in male broilers. Anim. Feed Sci. Technol. 65:215-230.

Promeyrat, A., P. Gatellier, B. Lebret, K. Kajak-Siemaszko, L. Aubry, and V. Santé-Lhoutellier. 2010. Evaluation of protein aggregation in cooked meat. Food Chem. 121:412-417.

Renkema, J. M. S., H. Gruppen, and T. van Vliet. 2002. Influence of $\mathrm{pH}$ and ionic strength on heat-induced formation and rheological properties of soy protein gels in relation to 
denaturation and their protein compositions. J. Agric. Food Chem. 50:6064-6071.

Rideau, N., Z. Nitzan, and P. Mongin. 1983. Activities of amylase, trypsin and lipase in the pancreas and small intestine of the laying hen during egg formation. Br. Poult. Sci. 24:1-9.

Sante-Lhoutellier, V., L. Aubry, and P. Gatellier. 2007. Effect of oxidation on in vitro digestibility of skeletal muscle myofibrillar proteins. J. Agric. Food Chem. 55:5343-5348.

Shacter, E. 2000. Quantification and significance of protein oxidation in biological samples. Drug Metab. Rev. 32:307-326.

Smet, K., K. Raes, G. Huyghebaert, L. Haak, S. Arnouts, and S. De Smet. 2008. Lipid and protein oxidation of broiler meat as influenced by dietary natural antioxidant supplementation. Poult. Sci. 87:1682-1688.

Stadtman, E. R. 1990. Metal ion-catalyzed oxidation of proteins: biochemical mechanism and biological consequences. Free Radic. Bio. Med. 9: 315-325.

Tang, C. H. and C. Y. Ma. 2009. Effect of high pressure treatment on aggregation and structural properties of soy protein isolate. LWT-Food Sci. Technol. 42:606-611.

Tang, X., Q. Wu, G. Le, J. Wang, K. Yin, and Y. Shi. 2012a. Structural and antioxidant modification of wheat peptides modified by the heat and lipid peroxidation product malondialdehyde. J. Food Sci. 77:H16-H22.
Tang, X., Q. Wu, G. Le, and Y. Shi. 2012b. Effects of heat treatment on structural modification and in vivo antioxidant capacity of soy protein. Nutrition 28:1180-1185.

Thomas, L., W. Plischke, and G. Storz. 1982. Evaluation of a quantitative solid phase reagent system for determination of blood analytes. Experiences with the analytes: LDH, bilirubin, BUN, glucose, and uric acid. Ann. Clin. Biochem. 19:214-223.

Witko-Sarsat, V., V. Gausson, and B. Descamps-Latscha. 2003. Are advanced oxidation protein products potential uremic toxins? Kidney Int. 63:S11-S14.

Wen, C., L. C. Wang, Y. M. Zhou, Z. Y. Jiang, and T. Wang. 2012. Effect of enzyme preparation on egg production, nutrient retention, digestive enzyme activities and pancreatic enzyme messenger RNA expression of late-phase laying hens. Anim. Feed Sci. Technol. 172:180-186.

Wu, D. W., X. Chen, X. Yang, Z. X. Leng, P. S. Yan, and Y. M. Zhou. 2014. Effects of heat treatment of soy protein isolate on the growth performance and immune function of broiler chickens. Poult. Sci. 93:326-334.

Zamora, R. and F. J. Hidalgo. 2001. Inhibition of proteolysis in oxidized lipid-damaged proteins. J. Agric. Food Chem. 49: 6006-6011.

Zhang, W., S. Xiao, E. J. Lee, and D. U. Ahn. 2011. Efects of dietary oxidation on the quality of broiler breast meat. Anim. Ind. Rep. AS 657, ASL R2624. 